\title{
Downward Departures from the Federal Sentencing Guidelines Based on the Defendant's Drug Rehabilitative Efforts
}

\author{
J. Gordon Seymour $\dagger$
}

As part of a wave of legislation intended to toughen federal criminal laws, ${ }^{1}$ Congress in 1984 passed the Sentencing Reform Act. ${ }^{2}$ Responding to perceived discrepancies in federal sentencing, ${ }^{3}$ the Act created the Federal Sentencing Commission to promulgate sentencing guidelines which would structure the imposition of sentences on convicted criminal defendants. ${ }^{4}$ Application of the Guidelines to a specific case produces a sentencing range within which the judge is normally expected to sentence the criminal offender. Choice of a sentence from within the range is not mandatory, however. The judge may depart from the guideline range if the court finds "that there exists an aggravating or mitigating circumstance of a kind, or to a degree, not adequately taken into consideration by the Sentencing Commission in formulating the Guidelines that should result in a sentence different from that described."

Some defendants have requested a downward departure from the Guidelines' sentencing range based on their successful rehabilitation or rehabilitative efforts in the period following arrest and preceding sentencing. Other defendants have based their request for departure on the grounds that there is a good chance they will be rehabilitated. Although courts are split as to whether such postoffense rehabilitation constitutes a valid ground for departure

† B.A. 1989, Yale University; J.D. Candidate 1993, The University of Chicago.

${ }_{1}^{1}$ Comprehensive Crime Control Act of 1984, Pub L No 98-473, 98 Stat 1837 (1987), codified at 18 USC $\S \S 3551-3742$ and 28 USC $\$ \S 991-998$ (1988).

2 Sentencing Reform Act of 1984, Pub L No 98-473, 98 Stat 1837, 1976 (1984).

3 Mistretta v United States, 488 US 361, 365 (1989) ("Serious disparities in sentences [l] were common.").

- See Comprehensive Crime Control Act of 1983, S Rep No 98-225, 98th Cong, 1st Sess 63 (1983), reprinted in 1984 USCCAN 3182, 3246.

s United States Sentencing Commission, Federal Sentencing Guidelines Manual § 5K2.0 (West, 1992) ("Guidelines Manual") (quoting 18 USC $\S 3553(b)$ (1988)). Some courts have concluded that in the absence of this departure privilege, the Guidelines would fail to comply with the due process requirement of the Fifth Amendment. See, for example, United States v Thomas, 884 F2d 540, 542-43 (10th Cir 1989). 
under the Guidelines, a substantial majority has concluded that a judge may not depart from the guideline range in this instance. This Comment argues that evidence of a defendant's affirmative efforts at drug rehabilitation prior to sentencing can be a valid grounds for departure from the Guidelines.

Section I addresses the creation and structure of the Guidelines. Section II delineates and critiques the primary arguments courts have made in finding such departures precluded. Section III scrutinizes the decisions that have allowed for the possibility of departure and illustrates the weaknesses in some of their arguments. Finally, Section IV proposes that the defendant's post-offense drug rehabilitation can be a legitimate ground for departure, when the defendant has exhibited genuine affirmative efforts at rehabilitation.

\section{The Guidelines' Background}

A. The Shift to Determinate Sentencing: The Sentencing Reform Act

In the late 1960s and early 1970s, criminologists and empirical researchers began to seriously examine the indeterminate sentencing system. What they found was widespread and unjustifiable disparity in sentences and a rate of recidivism that reflected the failure of prison reform programs. ${ }^{6}$ By the mid-1980s a consensus had developed that sentencing guidelines of some form were needed, 7 and Congress responded by enacting the Sentencing Reform Act of 1984. The Act created the Sentencing Commission, and gave it authority to promulgate federal sentencing guidelines. ${ }^{8}$

Although the Act outlined the purposes of sentencing, ${ }^{9}$ limited the types of punishment courts could impose, ${ }^{10}$ and provided for appellate review of sentencing decisions, ${ }^{11}$ the Act's directives to the Commission were largely advisory. For instance, the Commission was largely not required to include any particular factor in the

${ }^{6}$ Mene H. Nagel, Structuring Sentencing Discretion: The New Federal Sentencing Guidelines, $80 \mathrm{~J}$ Crim L and Criminol 883, $896 \mathrm{nn}$ 76-77 (listing studies).

7 This growing consensus was reflected at the state level. By the mid-1980s, thirteen states had adopted a guideline system. Sandra Shane-DuBow, Alice P. Brown, and Erik Olsen, Sentencing Reform in the United States: History, Content and Effect 290-92 (GPO, 1985).

${ }^{8}$ See 28 USC $\S \S 991,992$.

- 18 USC § 3553(a)(2).

1018 USC \& 3551 .

1118 USC \& 3742 . 
Guidelines, but was merely instructed to consider if a suggested list of factors should have any relevance to a sentencing decision. ${ }^{12}$

\section{B. The Commission's Product: Federal Sentencing Guidelines}

The Commission engaged in exhaustive hearings and produced several drafts of the Guidelines before agreeing on the version that took effect on November $1,1987 . .^{13}$ The Guidelines establish a twodimensional matrix for plotting the defendant's sentence. ${ }^{14}$ The vertical axis represents the severity of the defendant's offense ("offense level"), while the horizontal axis plots the defendant's criminal history ("criminal history category"). Correlating the defendant's position on each axis produces a guideline sentencing range. The judge is normally expected to select a sentence from within that range. ${ }^{15}$ Section 5K2.0 of the Guidelines, however, provides that a judge may depart from the specified sentencing range in certain instances:

[T] ] sentencing court may impose a sentence outside the range established by the applicable guideline, if the court finds "that there exists an aggravating or mitigating circumstance of a kind, or to a degree, not adequately taken into consideration by the Sentencing Commission in formulating the guidelines that should result in a sentence different from that described." Circumstances that may warrant departure from the guidelines pursuant to this provision cannot, by their very nature, be comprehensively listed and analyzed in advance. The controlling decision as to whether and to what extent departure is warranted can only be made by the courts $\ldots{ }^{16}$

The statute further specifies that in determining whether the Commission adequately considered a circumstance, the court may only consider the "sentencing guidelines, policy statements, and of-

1228 USC § 994(d) (directing the Commission to consider the relevance of certain offender characteristics). Note, however, that this same section directs the Commission to assure that the Guidelines are neutral as to the race, sex, national origin, creed, and socioeconomic status of offenders.

${ }^{23}$ Guidelines Manual ch 1 at 1 (cited in note 5). References to chapter 1 of the Guidelines Manual are to the official introduction. All other references use section numbers.

14 Id at $\S 5 \mathrm{~A}$.

15 Id, ch 1 at 1.

16 Id at $\S 5 \mathrm{~K} 2.0$ (quoting 18 USC $\S 3553(\mathrm{~b})$ (1988)). Other provisions of the Guidelines also allow for departure. See note 113. None of these other departure privileges are relevant to this Comment. 
ficial commentary of the Sentencing Commission."17 The legitimacy of a departure from the guideline range thus amounts to a survey of these sources for evidence of consideration by the Commission. Absent such consideration, any circumstance that "should result" in a different sentence is a legitimate ground for departure. ${ }^{18}$

Whether the Commission has adequately considered a given circumstance is not always self-evident, however. One context in which courts have disagreed over whether such consideration has taken place is the legitimacy of downward departure based on the defendant's rehabilitative efforts prior to sentencing. ${ }^{19}$

1718 USC $\S 3553(\mathrm{~b})$, as amended by the Sentencing Act of 1987, Pub L No 100-182, $\S$ 3,101 Stat 1266 (1988). Interestingly, this requirement was added to $\S 3553(\mathrm{~b})$ at the specific behest of Commission members who foresaw that without such a limitation their personal files might be discoverable in a dispute over the legitimacy of a departure. See 133 Cong Rec H10017 (daily ed, Nov 16, 1987).

${ }_{18}$ See United States $v$ Savage, 888 F2d 528, 529 (7th Cir 1989) ("[I]t takes an express direction to foreclose a particular consideration as a basis of departure."). This is not to imply that the Guidelines mandate a textualist interpretation. Rather, whatever theory of interpretation is employed in reading the Guidelines, the basis for finding the Commission's consideration must derive from a specific provision of the Guidelines, rather than a general impression of what the Commission must have thought about. This canon is reinforced by $\S$ 1B1.4, which allows the court to "consider, without limitation, any information concerning the background, character and conduct of the defendant, unless otherwise prohibited by law," in determining whether a departure from the Guidelines is warranted. Guidelines Manual $\$ 1 B 1.4$ (cited in note 5).

${ }^{10}$ Drug rehabilitation is not specifically mentioned as a legitimate ground for departure, nor is it specifically listed as a factor on which a departure cannot be based. The sole inquiry therefore is whether one of the Guidelines' provisions that does not specifically mention drug rehabilitation constitutes adequate consideration of that circumstance.

Courts holding that a defendant's drug rehabilitation is not grounds for departure in most circumstances include United States v Harrington, 947 F2d 956, 962 (DC Cir 1991) ("Harrington II"); United States v Sklar, 920 F2d 107, 116 (1st Cir 1990), cert denied, 111 S Ct 2274 (1991); United States v Pharr, 916 F2d 129, 130 (3d Cir 1990); United States v Van Dyke, 895 F2d 984, 987 (4th Cir 1990); United States $v$ Martin, 938 F2d 162, 164 (9th Cir 1991); United States $v$ Williams, 948 F2d 706, 710-11 (11th Cir 1991). In addition, the Seventh and Eighth Circuits have found departure precluded on account of the defendant's non-drug related rehabilitative efforts. United States v Bruder, 945 F2d 167, 173 (7th Cir 1991) (en banc); United States v Desormeaux, 952 F2d 182, 185-86 (8th Cir 1991) (attaining GED does not form basis for departure). While Sklar, Harrington II and Williams left open the possibility of a departure in certain unusual circumstances, these cases stressed the rarity of such circumstances and denied departure in the cases there under review.

Courts that have accepted post-offense drug rehabilitation as a legitimate basis for departure include United States v Maddalena, 893 F2d 815, 818 (6th Cir 1989); United States v Maier, 777 F Supp 293, 296 (S D NY 1991); United States v Davis, 763 F Supp 645, 652 (D DC 1991); United States v Floyd, 738 F Supp 1256 (D Minn 1990); United States $v$ Rodriguez, 724 F Supp 1118, 1119 (S D NY 1989). 


\section{Analysis and Criticism of Cases Not Allowing Departure For Drug Rehabilitative Efforts}

The courts that have refused to allow departure based on the defendant's post-offense drug rehabilitation have advanced four primary arguments: 1 ) the Commission adequately considered drug rehabilitation in the Guidelines' provision allowing a reduction in sentence based on the defendant's acceptance of responsibility; ${ }^{20}{ }_{2}$ ) the Commission adequately considered drug rehabilitation in the Guidelines' proscription against departing downward based on the defendant's drug dependency at the time of the crime; ${ }^{21} 3$ ) allowing a sentence reduction for drug rehabilitation is contrary to the Act's stated objective that imprisonment not be used as a means of promoting rehabilitation; and 4) allowing drug addicts a potential reduction is unfair to defendants who are not addicted to drugs. Underlying these arguments may be a more general concern that allowing such a departure amounts to a subversion of the Guidelines. This section addresses the validity of each of these arguments, concluding that each is significantly flawed and that drug rehabilitation is a legitimate ground for departure from the sentencing range.

\section{A. Acceptance of Responsibility}

The strongest argument against allowing departure is that drug rehabilitation has been afforded adequate consideration by the Commission under $\S 3 \mathrm{E} 1.1$, the acceptance of responsibility adjustment. Specifically, $\S 3 \mathrm{E} 1.1$ allows the judge to award the defendant a two point reduction in offense level when the defendant has "clearly demonstrate[d] a recognition and affirmative acceptance of personal responsibility for his criminal conduct."22 The section's commentary provides the court with a number of factors to consider in reaching this determination:

20 Guidelines Manual § 3E1.1 (cited in note 5).

${ }^{21}$ Id at $\S 5 \mathrm{H} 1.4$.

${ }^{22}$ Id at $\S 3 \mathrm{E} 1.1$ (a). At least one criminologist has assailed $\S 3 \mathrm{E} 1.1$ as a "guilty plea discount" that illegitimately provides an official reward for a guilty plea. See Albert W. Alschuler, Departures and Plea Agreements under the Sentencing Guidelines, 117 FRD 459, 471-72 (1987). See also Stephen Breyer, The Federal Sentencing Guidelines and the Key Compromises Upon Which They Rest, 17 Hofstra L Rev 1, 28-29 (1988) (acknowledging that the "Guidelines' solution to this problem [of defendants who plead guilty receiving a $30-40 \%$ lower sentence than those who plead not guilty and are subsequently convicted] is to provide a two-level discount ... for what the Guidelines call 'acceptance of responsibility.' "). Judge Breyer was an instrumental member of the Commission that drafted the Guidelines. 
(a) voluntary termination or withdrawal from criminal conduct or associations;

(b) voluntary payment of restitution prior to adjudication of guilt;

(c) voluntary and truthful admission to authorities of involvement in the offense and related conduct;

(d) voluntary surrender to authorities promptly after commission of the offense;

(e) voluntary assistance to authorities in the recovery of the fruits and instrumentalities of the offense;

(f) voluntary resignation from the office or position held during the commission of the offense; and

(g) the timeliness of the defendant's conduct in manifesting the acceptance of responsibility. ${ }^{23}$

The commentary points out that this list of factors is not meant to be exhaustive. A defendant that has taken "some equivalent action" may also be considered for a reduction under this section. ${ }^{24}$

Three arguments based on $\S 3 \mathrm{E} 1.1$ have emerged to support the notion that departure for drug rehabilitation is illegitimate under the Guidelines. In United States $v$ Van Dyke, the court characterized the defendant's drug rehabilitation as equivalent conduct to the actions listed in the commentary to $\S 3 \mathrm{E} 1.1 .^{25}$ Thus, the court concluded a departure based upon drug rehabilitation was not acceptable. The courts in United States $v$ Sklar, ${ }^{26}$ and United States $v$ Harrington (Harrington $I I^{27}$ adopted a slightly different approach. Rather than finding an actual part of the Guidelines' text that evinced the Commission's consideration of drug rehabilitation, they merely concluded that the Commission "must have considered" drug rehabilitation in formulating $\S 3 \mathrm{E} 1.1 .^{28}$ Finally, drug rehabilitation may have been considered in $\S 3 \mathrm{E} 1.1$ since the application notes instruct that "voluntary termination or withdrawal from criminal conduct" is relevant to assessing the defendant's acceptance of responsibility.

${ }^{23}$ Guidelines Manual § 3E1.1 (application notes) (cited in note 5). Note that unlike the commonly invoked "substantial assistance" departure provided for in $\S 5 \mathrm{~K} 1.1$, the downward adjustment for acceptance of responsibility need not be requested by the government's motion.

${ }^{24}$ Id at § 3E1.1 (background commentary).

25895 F2d 984, 987 (4th Cir 1990).

${ }^{28} 920$ F2d 107 (1st Cir 1990).

27947 F2d 956 (DC Cir 1991).

${ }^{28}$ Sklar, 920 F2d at 119; Harrington II, 947 F2d at 972. 
1. Drug rehabilitation as equivalent to the conduct listed in the commentary to $\S 3 \mathrm{E} 1.1$.

In Van Dyke, the Fourth Circuit painted in broad strokes in the course of reversing the district court's downward departure from the sentencing range. ${ }^{29}$ The defendant was convicted on charges of possession of a controlled substance. While held in pretrial detention, the defendant participated in a drug treatment program and counselled fellow inmates about drug abuse. The district court reduced the offense level for acceptance of responsibility under $\S 3 \mathrm{E} 1.1$, and then departed downward from the sentencing range stating that he was "satisfied that the defendant is trying to rehabilitate himself, and therefore I don't think a longer sentence is required." 30

The Court of Appeals reversed, lumping the defendant's efforts at rehabilitation into the broader category of post-offense conduct, which the court felt could not be considered a reason for downward departure. ${ }^{31}$ Specifically, the court argued that drug rehabilitation is conduct "equivalent" to the factors listed in the commentary to $\S 3 \mathrm{E} 1.1$. To make this comparison, the court described the factors listed in $\S 3 \mathrm{E} 1.1$ 's commentary, such as voluntarily making restitution or helping recover the fruits of the crime, as examples of "rehabilitative" conduct. ${ }^{32}$

The approach taken by the appeals court in Van Dyke has not been universally accepted. In fact, another panel of the same circuit that decided Van Dyke concluded that rehabilitation had nothing to do with the defendant's acceptance of responsibility. In United States $v$ Braxton, ${ }^{33}$ the Fourth Circuit reversed a district court's holding that rehabilitation was a necessary element of an

29 The Van Dyke opinion was written by Judge William W. Wilkins, Jr. of the Fourth Circuit, who is currently Chairman of the Sentencing Commission.

so Van Dyke, $895 \mathrm{~F} 2 \mathrm{~d}$ at 986 . The sentencing judge, confused over the applicable guideline range, sentenced the defendant to a period within the lower of two potentially applicable ranges, and announced that if his choice of range turned out to be incorrect, the sentence should be viewed as a downward departure. The appellate court found the longer of the two ranges applicable, and thus treated the imposed sentence as a downward departure.

${ }^{31}$ Id at 987. The court found departures based on "post offense conduct" foreclosed due to its having received adequate consideration in § 3E1.1's provision for "acceptance of responsibility," $\S 3 \mathrm{C} 1.1$ 's adjustment for "obstruction of justice," and § 5K1.1's allowance for "substantial assistance." Id at 986-87, $987 \mathrm{n} 1$. Such a broad contention is at odds with both the language of the Guidelines and a good deal of case law. See, for example, United States v Sanchez, 893 F2d 679, 681 (5th Cir 1990) (allowing an upward departure based on the defendant's "continued unlawful behavior" while on release after his arrest).

${ }^{32}$ Van $D y k e, 895$ F2d at 987.

s3 903 F2d 292 (4th Cir 1990), rev'd on other grounds, 111 S Ct 1854 (1991). 
acceptance of responsibility. The lower court denied this reduction to the defendant on the grounds that he was incapable of being rehabilitated. In reversing the sentencing court, the court emphasized that the word "rehabilitation" is not used in $\S 3 \mathrm{E} 1.1$, its application notes, or commentary, has not been considered in any case construing § 3E1.1 (apparently the court overlooked Van Dyke), and concluded that the district court had "misperceived the purpose of the guideline [ $\S 3 \mathrm{E} 1.1]$ by interjecting into the calculus a need for rehabilitation." 34

One could technically reconcile Braxton and Van Dyke on the grounds that Braxton only holds that rehabilitation is not a sine qua non of a reduction for acceptance of responsibility. ${ }^{35}$ There is no doubt, however, that the breadth of the case's language casts doubt on the continued vitality of the Fourth Circuit's earlier pronouncement in Van Dyke.

Braxton is not alone; even appellate courts holding that a sentencing court may not depart downward on the basis of the defendant's drug rehabilitation have found rehabilitation irrelevant to assessing the defendant's acceptance of responsibility under $\S$ 3E1.1. In United States v Pharr, the Third Circuit found drug rehabilitation inconsistent with the underlying nature of the factors included in $\S 3 \mathrm{E} 1.1 .^{36}$ Pharr, a heroin addict, had entered and successfully completed an inpatient drug rehabilitation program prior to his sentencing. ${ }^{37}$ Finding that the Guidelines did not give adequate consideration to the defendant's "conscientious efforts" to overcome his heroin addiction or the effects of incarceration on those efforts, the district court adjusted Pharr's sentence to reflect the acceptance of responsibility, and then departed downward. ${ }^{38}$

The appellate court reversed the departure, and held that Pharr was not eligible for the acceptance of responsibility adjustment either. In reaching the latter conclusion, the court reasoned that the list of factors in the commentary to $\S 3 \mathrm{E} 1.1$ "relate to actions by the defendant either accepting responsibility for the offense for which he is being sentenced or mitigating the effects of his criminal activity." ${ }^{39}$ In contrast, Pharr's actions in entering a drug rehabilitation program were only attempts at "self-improve-

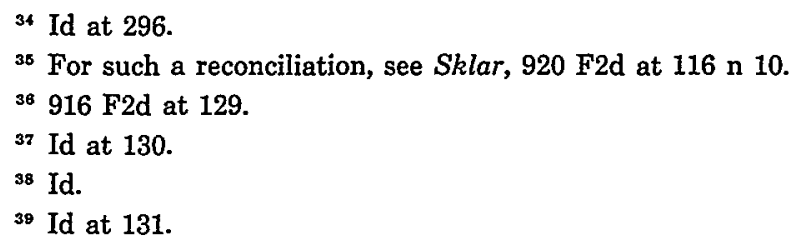


ment"- "not the type of conduct contemplated by the acceptance of responsibility provisions of the guidelines." 40

While the court's attempt to create a simple dichotomy between accepting responsibility and self-improvement rings a bit false, there is an underlying truth to their observations: drug rehabilitation does not seem to match the purposes of $\S 3 \mathrm{E} 1.1$. Each of the factors requires either cooperation with the authorities in processing the case through the criminal justice system ${ }^{41}$ or in remedying the harm caused by the crime. ${ }^{42}$ Drug rehabilitation does not fit comfortably within either of these categories; its connection to the notion of acceptance of responsibility for the crime committed-be it drug-related or not-is much more attenuated than any of the factors listed in $\S 3 \mathrm{E} 1.1$. This insight is even more powerful if, as some commentators have argued, $\S 3 \mathrm{E} 1.1$ is actually a "guilty plea discount" which operates to provide an official reward for a guilty plea. ${ }^{43}$ Given this objective, it is difficult to see what the defendant's drug rehabilitation could do to further this goal.

\section{What the Commission "must have considered."}

Several courts have rejected the notion that drug rehabilitation can be grounds for departure by relying on a speculative assessment of what the Commission must have considered in drafting $\S 3 E 1.1$. This method of reading the Guidelines is improper.

In United States $v$ Sklar, ${ }^{44}$ a panel of the First Circuit reversed the district court's downward departure on the basis of the

40 Id. See also Harrington II, 947 F2d at 970-71 (Silberman dissenting). In Pharr, the court distinguished Van Dyke on the grounds that "Van Dyke's drug rehabilitation efforts were directly related to the crime for which he was being sentenced" (possession of heroin with intent to distribute), suggesting that drug rehabilitation could be an acceptance of responsibility only when the defendant's crime is "drug related." Pharr, 916 F2d at 132.

The court did not specify which crimes qualify as "drug related," but it seems to require more than a causal connection between drug addiction and commission of the crime (in Pharr, the defendant acknowledged that he was an addict and that this addiction caused him to sell stolen U.S. Treasury checks, but his crime was not considered "drug related"). However, a narrow interpretation of which crimes are "drug related"-only those involving the use or distribution of drugs-may lead to arbitrary results. Compare with Pharr a defendant who has smuggled drugs for years because she reaps a generous profit from the trade and enjoys the danger. A month prior to her arrest for distribution, she starts to regularly use her product. After arrest, she quickly breaks the addiction and, by Pharr's logic, is thus eligible for a two-level reduction for accepting responsibility.

"1 See Guidelines Manual § 3E1.1 (application note 1, parts (a), (c), (d), and (f)) (cited in note 5).

42 Id at $\S 3 \mathrm{E} 1.1$ (application note 1, parts (b) and (e)).

43 See note 22.

1" 920 F2d 107 (1st Cir 1990). 
defendant's attempts at rehabilitation in the year following his arrest and preceding his sentence. The court concluded that the Commission "seems to have factored presentence rehabilitation into a two level reduction in the offense level for acceptance of responsibility under U.S.S.G. § 3E1.1." 45 The court provided no reasons why drug rehabilitation falls under $\S 3 \mathrm{E} 1.1$. Rather, the court apparently based this finding on its impression of what the Commission must have considered:

To assume that there was a qualitative failure-an oversight in not featuring presentence rehabilitation more prominently in the guidelines-beggars credulity. Cf. United States $v$. Pozzy, 902 F.2d 133, 139 (1st Cir. 1990) (defendant's pregnancy held not to be a factor warranting downward departure; Sentencing Commission must have been fully aware that some convicted female felons are pregnant at the time of sentencing"). ${ }^{46}$

The legitimacy of this analysis, however, is far from clear. The Sklar opinion, as did the Pozzy opinion it relied upon, finds consideration merely by speculating as to what the Commission must have considered rather than by finding consideration in the text of the Guidelines itself. Such reasoning flouts the very structure of the departure privilege by creating a presumption against departure when the Commission has not addressed a particular circumstance. ${ }^{47}$ The Act, however, makes clear that the adequate consideration test is not a license to embark on a journey into the minds of the Commissioners. ${ }^{48}$ Rather than relying on speculation about the Commission's thought processes, consideration of a circumstance must be grounded in a portion of the Guidelines' text. If such a basis cannot be found in the text, then the circumstance has to be deemed to have not been considered by the Commission.

3. Voluntary withdrawal from criminal conduct.

One possible textual anchor for the argument that drug rehabilitation was considered in $\S 3 \mathrm{E} 1.1$ is the language in the application notes to $\S 3 \mathrm{E} 1.1$ to the effect that "voluntary termination or withdrawal from criminal conduct or associations" is a factor relevant to determining whether the defendant has accepted responsi-

\footnotetext{
15 Id at 115-16.

48 Id at 116.

17 See note 18 and accompanying text.

48 See note 17 and accompanying text.
} 
bility. ${ }^{49}$ Because drug use is criminal conduct, the defendant's voluntary termination of drug use (i.e., the defendant's rehabilitation) is a factor in assessing whether the defendant has accepted responsibility. Therefore, the argument goes, drug rehabilitation has been considered in $\S 3 \mathrm{E} 1.1$ and is accordingly not an available grounds for departure..$^{\mathrm{so}}$

A closer look at this argument, however, reveals several compelling counterarguments. First, this argument creates an arbitrary distinction between rehabilitations from drug abuse (which is generally criminal conduct) and alcohol abuse (which is generally not criminal conduct). There is no reason to think that the Commission sought to require defendants addicted to drugs to do more than defendants addicted to alcohol to gain the acceptance of responsibility reduction. In fact, the distinction is belied by the equivalent treatment of these two afflictions in other sections of the Guidelines. ${ }^{\text {s1 }}$ Second, the connection between this application note and the defendant's drug rehabilitation is so happenstance that it should not qualify as adequate consideration. A finding of adequate consideration should not turn on the fortuity that a general provision of the Guidelines can be said to encompass the situation at issue. Rather, it must be clear that the Commission actually considered the circumstance in question. Such consideration is not apparent in the phrase "voluntary termination or withdrawal from criminal conduct."

\section{B. Physical Condition Including Drug Dependence and Alcohol Abuse}

The second argument which courts have relied upon in denying departure rests on $\S 5 \mathrm{H} 1.4$, a policy statement ${ }^{52}$ that provides in relevant part:

19 Guidelines Manual \& 3E1.1 (application note 1(a)) (cited in note 5).

so There is some general support for this approach in the case law. This application note has been relied upon by appellate courts upholding sentencing courts' refusal to grant a $\S 3$ E1.1 reduction to defendants convicted of drug-related offenses that have used narcotics after their arrest. See United States v Scroggins, 880 F2d 1204, 1215-16 (11th Cir 1989) (considering defendant's continued use of cocaine); United States $v$ Weidner, $703 \mathrm{~F}$ Supp 1350,1354 (N D Ind 1988) (considering defendant's failure of a urine test). See also United States $v$ Watkins, 911 F2d 983, 985 ("We note that this factor is phrased in general terms and does not specify that the defendant need only refrain from criminal conduct associated with the offense of conviction in order to qualify for the reduction.").

${ }^{31}$ See for example, Guidelines Manual § 5H1.4 (cited in note 5) ("Drug dependence or alcohol abuse is not a reason for imposing a sentence below the guidelines.").

${ }^{62}$ Section 5 H1.4 is a "policy statement," not a "guideline." While the courts have generally treated the two as equivalent, some commentators have argued that this difference 
Drug or alcohol dependence or abuse is not a reason for imposing a sentence below the guidelines. Substance abuse is highly correlated to an increased propensity to commit crime. Due to this increased risk, it is highly recommended that a defendant who is incarcerated also be sentenced to supervised release with a requirement that the defendant participate in an appropriate substance abuse program. ${ }^{\mathrm{s}}$

The courts that have found that the Commission considered drug rehabilitation in this provision have supported their position with only cursory assertions. Pharr is typical: "We read policy statement 5H1.4 to mean that dependence upon drugs, or separation from such a dependency, is not a proper basis for a downward departure from the guidelines." ${ }^{4}$ Judge Silberman's dissent in Harrington II may well have expressed this argument the most cogently. The dissent argued that the Commission's explicit rejection of drug dependence as grounds for a downward departure implicitly included a rejection of drug rehabilitation: "After all, rehabilitation is not relevant unless one is dependent."ss

These arguments turn on the superficial similarity between drug dependence and rehabilitation from drug dependence. ${ }^{56}$ Such reasoning, however, conflicts with the rationale behind this policy statement. The policy statement reflects a shift from a retributive concept of punishment (where the defendant is less culpable when her clouded mental state prevented her from being fully aware of her criminal actions and their consequences) to a deterrent rationale for punishment (where the defendant's addiction renders her more likely to commit further crimes and thus heightens the need for punishment). Accordingly, it would be improper to adjust the defendant's sentence downward from the guideline range because of a defendant's impaired awareness at the time of a crime. However, $\S 5 \mathrm{H} 1.4$ 's concern with "propensity to commit [future] crime," makes it incongruous to prohibit departure when a defend-

bears on the deference courts should accord the two. See, for example, Marc Miller and Daniel J. Freed, Offender Characteristics and Victim Vulnerability: The Difference Between Policy Statements and Guidelines, 3 Fed Sent Rptr 3 (1990). But see Williams v United States, 112 S Ct 1112, 1119-20 (1992).

${ }^{83}$ Guidelines Manual \$ 5H1.4 (cited in note 5).

o4 Pharr, 916 F2d at 133. See also United States v Martin, 938 F2d 162, 163-64 (9th Cir 1991).

${ }^{s 5}$ Harrington II, 947 F2d at 970 (Silberman dissenting).

${ }^{58}$ While the dissent in Harrington II was more precise than Martin and Pharr in calling rehabilitation and dependence "companion concepts" rather than equivalents, all three arguments are flawed to the extent they conflate these two different ideas. 
ant has reduced such propensity by breaking her addiction to drugs. If anything, the provision's emphasis on deterrence seems to lend credence to a departure based on the defendant's rehabilitation. If a court concludes that drug addiction motivated the defendant to commit a crime, it should follow that the rehabilitated defendant poses not only less of a threat of recidivism than an addicted criminal, but even less of a threat than a non-addict defendant (of whom the court cannot be sure that the motivation to commit the crime has dissipated). ${ }^{57}$

Several courts have also argued that the Commission adequately considered drug rehabilitation in $\S 5 \mathrm{H} 1.4$ 's recommendation that addicted offenders be required to undergo drug treatment as a condition of their supervised release after incarceration. ${ }^{58}$ This argument, however, is also misleading. As the full text of $\S 5 \mathrm{H} 1.4$ reveals, the recommendation that the court require an offender to participate in such a program stems from the "increased risk" of recidivism posed by an addict. The explicitly deterrent rationale of the requirement suggests that it is inapplicable to a rehabilitated offender. Furthermore, the mere mention of "drug rehabilitation" as a condition of an addicted offender's probation does not lead to the conclusion that the Commission adequately considered the altogether different circumstance of the defendant who rehabilitates himself prior to going to prison. Section 5H1.4's recommendation simply does not apply to, and hence cannot constitute consideration of, a rehabilitated defendant. ${ }^{.9}$

\section{Congress's Purported Rejection of Rehabilitation as a Goal of Sentencing}

Courts denying the availability of departure have also claimed that a departure for drug rehabilitation is inconsistent with their

${ }^{67}$ The district court in United States v Harrington, 741 F Supp 968 (D DC 1990) ("Harrington I"), vacated, 947 F2d 956 (DC Cir 1991) ("Harrington II"), recognized this point. Citing $\S 5 \mathrm{H} 1.4$ 's statement that "[s]ubstance abuse is highly correlated to an increased propensity to commit crime," the court noted: "There is an obvious negative pregnant in this statement by the Commission: successful treatment for drug abuse could lead to a reduced propensity to commit crime and thereby reduce the need for [] longer periods of incarceration ...." Id at 975-76. See also United States $v$ Williams, 948 F2d 706, 710 (11th Cir 1991) ("Section 5H1.4 does not prohibit downward departures based on recoveries; it merely prohibits downward departures on the basis of a defendant's theoretical diminished capacity because of his drug dependence.").

so See Martin, 938 F2d at 164; Harrington II, 947 F2d at 970 (Silberman dissenting).

s9 See also Williams, 948 F2d at 710 (arguing that the Ninth Circuit in Martin "read too much into the Commission's recommendation for supervised release conditioned on drug treatment"). 
perception of the role of rehabilitation in the new sentencing regime. ${ }^{60}$ These courts first note (correctly) that the Act marked a shift away from a "medical" sentencing model in which sentences are designed to reflect the amount of time it will take the defendant to be rehabilitated. ${ }^{61}$ They support this position by referring to the language in the Act that the Guidelines should reflect the "inappropriateness of imposing a sentence to a term of imprisonment for the purpose of rehabilitating the defendant . . .."62 Courts have concluded from this that rehabilitation is an inappropriate consideration in the new sentencing system. ${ }^{63}$

This reasoning, however, is mistaken. Congress and the Commission consciously chose to retain rehabilitation as a purpose of sentencing. ${ }^{64}$ In one of the most important and controversial portions of the statute, the Act specifically required that the sentencing court shall consider, among other things, "the need for the sentence imposed ... to provide the defendant with needed educational or vocational training, medical care, or other correctional treatment in the most effective manner . . . ${ }^{65}$

The Act proceeds to explain the role of this last factor-rehabilitation-in sentencing:

The court, in determining whether to impose a term of imprisonment, and, if a term of imprisonment is to be imposed, in determining the length of the term, shall consider the factors set forth [above] to the extent that they are applicable, recognizing that imprisonment is not an appropriate means of promoting correction and rehabilitation. ${ }^{66}$

Read together, these sections appear to require the judge to consider the prospect of the defendant's rehabilitation in imposing a

${ }^{60}$ See, for example, Sklar, 920 F2d at 115.

${ }^{61}$ See text at note 6 .

${ }^{62} 28$ USC § 994(k) (1988).

${ }^{63}$ See, for example, Sklar, 920 F2d at 115 ("It is crystal clear that Congress largely rejected rehabilitation as a direct goal of criminal sentencing under the guidelines.").

64 See 18 USC § 3553(a)(2)(D) (1988); United States v Lara, 905 F2d 599, 604 (2d Cir 1990) ("[A]lthough the role of rehabilitation in sentencing has been sharply restricted by the Guidelines, rehabilitation has not been entirely eliminated from the sentencing process."). See also Nagel, $80 \mathrm{~J}$ Crim L \& Criminol at 916 (cited in note 6) ("[A] careful reading of the exact statutory language ultimately adopted, together with a review of the legislative history, makes clear that commitment to a single explicit rationale ... would be in direct contradiction to the intent of the enabling legislation."). Professor Nagel was a member of the Commission that adopted the Guidelines.

${ }^{68} 18$ USC \& $3553(\mathrm{a})$. The sentencing court is also instructed to consider retribution, general deterrence and incapacitation.

${ }^{\text {в8 }} 18$ USC $\S 3582(a)$. 
sentence, while prohibiting a sentence of imprisonment solely to provide needed services to the prisoner.

While the Act did "reject[] imprisonment as a means of promoting rehabilitation," ${ }^{\circ}$ there is a difference between imprisonment imposed in order to rehabilitate the defendant and the defendant's rehabilitation as grounds for a reduction in the length of a sentence. ${ }^{68}$ The distinction becomes more apparent when it is realized that the warning about using imprisonment as a means of promoting rehabilitation is narrowly tailored to prevent judges from imposing a sentence of imprisonment just because the prison offers a rehabilitative program that the judge feels may be of use to the defendant. The Senate Report on the Act explicitly recognized this point. It states that the provision was meant to "discourage the employment of a term of imprisonment on the sole ground that a prison has a program that might be of benefit to the prisoner." ${ }^{\text {ge }}$ Members of the Commission have also recognized that this provision does not abandon rehabilitative considerations, but that "it intended to make clear that imprisonment should not be the sentence of choice if the primary purpose for the sanction is rehabilitation of the offenders." provide a place for rehabilitation in the sentencing regime, but affirmatively requires judges to consider the potential impact of a sentence on the defendant's rehabilitation in determining the length of the sentence. ${ }^{71}$

D. Fairness to Non-Addicts

Other courts have argued that to allow a departure for defendants who have rehabilitated themselves would be unfair to defendants who are not addicted to drugs and thus do not have a chance

${ }^{87}$ Mistretta, 488 US at 367 (citing 28 USC $\S 994(\mathrm{k})$ (1988)) (emphasis added).

${ }^{68}$ See Harrington I, $741 \mathrm{~F}$ Supp at 975 . Throughout the sentencing reform process, criminologists have emphasized that the purposes of incarceration and the reasons for punishing someone are distinct inquiries. See, for example, Norval Morris, The Future of Imprisonment 58-84 (Chicago, 1974).

69 S Rep No 98-225, in 1984 USCCAN at 3302 (cited in note 4) (emphasis added).

70 Nagel, $80 \mathrm{~J}$ Crim L \& Criminol at $901 \mathrm{n} 109$ (cited in note 6) (emphasis added).

${ }^{71} \mathrm{~S}$ Rep No 98-225 in 1984 USCCAN at 3258 (cited in note 4) (The factors laid out in 18 USC $\$ 3553$ (a) "appl[y] to both the appropriate type of sentence (e.g., fine, probation, imprisonment, or a combination thereof) and to the severity of the sentence." (emphasis added)). Note, however, that once imposed, a defendant's sentence may not be modified unless the court finds "extraordinary and compelling reasons warrant such a reduction." 18 USC $\$ 3582(\mathrm{c})(1)(\mathrm{A})$. The statute goes on to provide that "[r]ehabilitation of the defendant alone shall not be considered an extraordinary and compelling reason." 28 USC § 994(t). 
to gain such a reduction. ${ }^{22}$ The courts have given this argument a statutory basis by arguing that such a departure would violate Congress's mandate that like defendants who have committed like offenses be punished similarly. ${ }^{73}$

An exaggerated notion of the uniformity the Guidelines sought to achieve seems to underlie these arguments. The Guidelines simply did not seek to prevent courts from drawing any distinctions between offenders with the same criminal history who have committed the same offense. In fact, a number of the provisions of the Act differentiate among similarly-situated offenders. ${ }^{74}$ For instance, the Guidelines' provision for a downward departure from the specified sentencing range for "substantial assistance to authorities" creates as many apparent anomalies as would allowing a downward departure for drug rehabilitation. Under $\$ 5 \mathrm{~K} 1.1$, a defendant can receive a sentence lower than that specified by the Guidelines if she has provided assistance in the investigation or prosecution of another person who has committed an offense. The provision specifically mentions that the judge may consider "the nature and extent of the defendant's assistance." 75 As several courts have noted, $\S 5 \mathrm{~K} 1.1$ provides a benefit to defendants who are more heavily involved in criminal activities and thus have more information to offer to the government. ${ }^{76}$ Despite the resultant "unfairness" to defendants who are not heavily involved in criminal activities, $\S 5 \mathrm{~K} 1.1$ is undoubtedly a legitimate basis for departure. Consequently, it seems that the analogous anomalies poten-

${ }^{72}$ See Pharr, 916 F2d at 133; Martin, 938 F2d at 164.

${ }^{73}$ See 18 USC \$ 3553(a)(6).

${ }^{74}$ The court in Rodriguez enumerated the pervasiveness of individual characteristics in Congress's sentencing scheme:

Section 991(b)(1) specifies . . . that sentences provide "fairness" and "reflect to the extent practicable advancement in knowledge of human behavior as it relates to the criminal justice process." Section 3552 provides for a "presentence investigation of a defendant"; a court which desires more information "may order a study of the defendant," as well as a psychological examination. Section 3553 provides that the sentence should be "sufficient, but not greater than necessary to comply with [specified] purposes" including "(A) ... to provide just punishment ... [and] (C) to protect the public from further crimes of the defendant." This discretion unquestionably envisions more severe sentences for defendants considered more likely to commit further crimes and less severe sentences for those unlikely to commit crimes. 18 U.S.C. $\$ 3553(a)(2)(C)$.

724 F Supp at 1120.

${ }_{75}$ Guidelines Manual $\$ 5 \mathrm{~K} 1.1(\mathrm{a})(3)$ (cited in note 5). The commentary stresses that "[s]ubstantial weight should be given to the government's evaluation of the extent of the defendant's assistance ...." Id (application note 3).

${ }^{78}$ See, for example, Floyd, 738 F Supp at 1259. 
tially created by allowing departure for drug rehabilitation are not inconsistent with the spirit of the Guidelines.

\section{E. The Scope of the Departure Privilege}

Parsing the Guidelines to reach the conclusion that the Commission has not considered post-offense drug rehabilitative efforts ignores the degree to which appellate courts' decisions whether to recognize departures may be influenced by broader considerations of the frequency of departure in the Guidelines system. Some of the courts that have denied departures seem to have been motivated by the impression that departures violate the spirit of the Guidelines and ruin any uniformity the system hoped to achieve. ${ }^{77}$ Others may have perceived departures based on the defendant's post-offense rehabilitation as merely a tacit way of reducing the relatively stiffer sentences that the Guidelines impose on first-time offenders who were addicted at the time they committed their offense. ${ }^{78}$ Some district court judges have fundamental disagreements with the Guidelines that undoubtedly inform their sentencing decisions, making them less hesitant to depart from the Guidelines' sentencing ranges. ${ }^{79}$ Conversely, some appeals court judges seem to view a district court's choice to depart downward from the guideline range as infidelity to-if not outright subversion of - the new system. ${ }^{80}$ Adding to the confusion, the Circuits have not been consistent in their approach to discretion in departing from the Guidelines. ${ }^{81}$

77 See, for example, Van Dyke, 895 F2d at 987 ("The primary Congressional objective embodied in the Sentencing Reform Act [] was to produce consistency and uniformity in sentencing, a worthy goal which requires us to put some of the practices of the past aside.").

${ }^{78}$ Such an impression may not be mere speculation either. See Harrington $I$, 947 F2d at 967 (Edwards concurring) ("This case is an example of how the Guidelines work at their worst. Although Harrington's crime was admittedly serious, he was a first offender and was addicted to narcotics.").

70 See Harrington II, 947 F2d at 963-70 (Edwards concurring) (includes an appendix compiling judicial criticism of the Guidelines); United States $v$ Rodriguez, 724 F Supp 1118 (S D NY 1989).

${ }^{80}$ See Stephen J. Schulhofer, Assessing the Federal Sentencing Process: The Problem is Uniformity, Not Disparity (forthcoming) ("The superficial analysis and strained logic of so many appellate decisions suggests that part of what is at work is a general view that departures are a threat to the guidelines system, so that the appellate judges must maintain pressure to confine discretion and keep departures to a minimum.").

${ }^{81}$ Compare United States v Lara, 905 F2d 599, 604 (2d Cir 1990); United States v Roberson, 872 F2d 597, 601, 602 n 4 (5th Cir 1989); United States v Rodriguez, 882 F2d 1059, 1068 (6th Cir 1989); United States v Jordan, 890 F2d 968, 973 (7th Cir 1989); with United States $v$ Williams, 891 F2d 962, 964 (1st Cir 1989). 
This confusion is understandable. The very notion of a "guideline" presupposes a balancing between rigidity and flexibility. The Act reflects this delicate balance. ${ }^{82}$ Congress instructed the Commission to establish practices that "avoid[] unwarranted sentencing disparities among defendants with similar records ... while maintaining sufficient flexibility to permit individualized sentences when warranted by mitigating or aggravating factors . . .."83

While the Commission actually created a fairly broad departure privilege in the Guidelines, it clearly favored a chary approach to its use. ${ }^{84}$ The legislative history of the Act, however, emphasizes the Guidelines' flexibility:

The Committee does not intend that the guidelines be imposed in a mechanistic fashion. It believes that the sentencing judge has an obligation to consider all the relevant factors in a case and to impose a sentence outside the guidelines in an appropriate case. The purpose of the sentencing guidelines is to provide a structure for evaluating the fairness and appropriateness of the sentence for an individual offender, not to eliminate the thoughtful imposition of individualized sentences. Indeed, the use of sentencing guidelines will actually enhance the individualization of sentences as compared to current law. ${ }^{85}$

Flexibility is also critical when one considers that the Guidelines are evolutionary. The Commission plans to refer to the reasons judges cite for departing from the Guidelines as a basis for making future refinements to the Guidelines. ${ }^{86}$ Since the Commission essentially retains the power to sharply restrict, if not pre-

82 This tension also reflects the legislative compromise that gave birth to the Act. In the course of the congressional wrangling over the implementation of the Guidelines, the House secured an amendment to the language of the departure privilege that seems to have softened any stricture implicit in the original formulation against excessive departure. However, Senate leaders, forced to agree to the amendment to avoid delay in the implementation of the Guidelines, stressed that they did not understand the amendment to broaden the departure privilege. See Nagel, $80 \mathrm{~J}$ Crim and Criminol at 938-39 n 290 (cited in note 6).

${ }_{33} 28$ USC $\S 991(\mathrm{~b})(1)(B)$.

84 Guidelines Manual, ch 1 at 7 (cited in note 5) ("[T]he Commission believes that despite the courts' legal freedom to depart from the guidelines, they will not do so very often.").

8s $S$ Rep No 98-225, in 1984 USCCAN at 3235-36 (cited in note 4) (emphasis added). See also id at $3235 \mathrm{n} 71$ (anticipating that the rate of departures under the Guidelines will be about $20 \%$ ).

${ }^{88}$ See id at 3263 (requiring statement of reasons when judge departs "assists the Sentencing Commission in its continuous reexamination of its guidelines and policy statements."). See also Breyer, 17 Hofstra L Rev at 18 (cited in note 22). 
clude, judicial consideration of any factor by mentioning that it has been considered, there is a strong argument for erring on the side of allowing a questionable factor to be considered in departing. ${ }^{87}$ Allowing departures based on drug rehabilitation affords courts the necessary flexibility envisioned by the Act, and offers the Commission the bounty of the courts' practical experience when future revisions are contemplated.

\section{Analysis and Criticism of Cases Allowing Departure}

While only one appellate court has endorsed a departure based on drug rehabilitation, ${ }^{88}$ a number of lower courts have made such departures. ${ }^{89}$ With several notable exceptions, ${ }^{80}$ however, those courts have provided few reasons for doing so. Since departure is allowed when a factor has not been adequately considered by the Commission, the task of a court seeking to depart is largely a negative one. There is little room for affirmative findings since a court choosing to so depart must find that no provision of the Guidelines indicates that the Commission considered drug rehabilitation.

\section{A. The Propriety of Individualized Consideration}

In United States $v$ Rodriguez, the district court for the Southern District of New York attacked the perceived rigidities of the

${ }^{87}$ See United States $v$ Correa-Vargas, 880 F2d 35, 40 (2d Cir 1988) (allowing the district court discretion to depart because the "dynamic relationship" between the Commission and the courts ensures that the Commission can limit such discretion if it desires to); United States v Smith, 909 F2d 1164, 1168-69 (8th Cir 1990), cert denied, $111 \mathrm{~S} \mathrm{Ct} 691$ (1991) ("There is a growing awareness of measured play in the joints of the Guidelines .... By acknowledging and explaining the departures required to do justice, sentencing courts-like the juries Justice Holmes envisioned working pure the law of negligence-contribute to a better set of future guidelines.").

${ }^{88}$ Maddalena, $893 \mathrm{~F} 2 \mathrm{~d}$ at $817 \mathrm{n} 1$ (remanding because the judge's remarks at sentencing suggested he was not aware he had the power to depart from the guideline range pursuant to $\S 5 \mathrm{~K} 2.0$ based on extensive rehabilitative efforts over the course of at least nine years). It is not clear from the opinion whether the court was considering efforts the defendant made after his conviction, or merely the defendant's efforts to stay away from drugs in the years preceding his conviction. For an argument that the Maddalena court only considered the latter, see Harrington II, 947 F2d at 961. But see United States v Maddelena, 931 F2d 57 (6th Cir 1991) (Appeal after remand dismissed for lack of jurisdiction. The district court "recognized that it had discretion to depart downward, but chose not to depart" on account of the defendant's "potential for drug rehabilitation.") (emphasis added).

s9 See note 19.

90 United States v Rodriguez,724 F Supp 1118 (S D NY 1989); Harrington I, 741 F Supp 968 (D DC 1990), vacated, 947 F2d 956 (DC Cir 1991); United States v Davis, 763 F Supp 645 (D DC 1991). 
Guidelines in the course of departing downward on the basis of the defendant's drug rehabilitation. ${ }^{91}$ After his arrest for selling $\$ 10$ worth of crack, Rodriguez overcame his addiction, remained drug free for two years, reunited with his wife and children, assumed responsibilities for his family, obtained employment, and took classes to better his job opportunities. ${ }^{92}$ After noting that the "rehabilitation of a drug addict by his act of will is no mean accomplishment," 93 the court concluded that it would be "senseless, destructive and contrary to the objectives of the criminal law to now impose a year's jail term on this defendant." ${ }^{4}$

In the course of deciding to depart downward, Judge Leval launched a frontal assault on what he felt was a "widespread but serious misconception that Congress . . . intended to do away.with consideration of the personal characteristics of the offender." Canvassing the statute, the court noted a number of places in which the Act directs courts to consider the personal characteristics of the defendant" and concluded that "the Commission expressly acknowledged the need in the 'atypical' case for invocation of the departure power to give appropriate effect to personal characteristics." Af After pointing out that courts have relied on this departure privilege in instances analogous to drug rehabilitation and noting that the Commission planned to base revisions to the Guidelines on their observations of judges' departure practices, the court concluded that a downward departure was both allowable and warranted. ${ }^{98}$

B. Restating the Inquiry: "An Amenability to Drug Treatment" as Grounds for Departure

In Harrington $I^{99}$ and United States $v$ Davis, ${ }^{100}$ Judge Oberdorfer of the District Court for the District of Columbia provided an alternative rationale for departure. Rather than inquiring

91 $724 \mathrm{~F}$ Supp at $1119-20$.

${ }^{22}$ Id at 1119.

${ }^{3}$ Id.

${ }^{94}$ Id. Although the statute under which the defendant was convicted did not mandate imprisonment, one year was the minimum statutory sentence. Since the guideline range was eight to fourteen months, if the court had chosen not to depart, the defendant would have to have been sentenced to at least one year. Id.

95 Id.

${ }^{96}$ Id.

97 Id at 1121 .

${ }^{88}$ Id at 1122-23.

89 741 F Supp 968.

100763 F Supp 645. 
into the defendant's desire for rehabilitation or rehabilitative progress, Judge Oberdorfer focused on whether the defendant was amenable to successful drug treatment. ${ }^{101}$

Surveying the Guidelines and relying on an amicus memorandum on the subject, Judge Oberdorfer in Harrington $I$ first found that the Commission never considered the circumstance of a defendant who was determined to be a particularly good candidate for rehabilitation. ${ }^{102} \mathrm{He}$ then determined that the defendant was amenable to successful drug rehabilitation, citing evidence that drug rehabilitative efforts are effective and noting that the defendant had exhibited characteristics highly correlated to successful drug rehabilitation. ${ }^{103}$ In particular, the court relied upon the sentencing report, an examination of the defendant by a court-appointed psychiatrist and his associate, letters from three officials involved with the defendant's drug treatment program, written and oral reports by the defendant's probation officer, and the court's own observation of the defendant in his several appearances. ${ }^{104}$ Specifically, Judge Oberdorfer found that the defendant exhibited maturity and devotion to his intensive drug treatment program. ${ }^{105}$

In Davis, Judge Oberdorfer further developed this analysis. He distinguished cases like Van Dyke that concluded that the Commission incorporated the defendant's drug rehabilitation into the acceptance of responsibility adjustment on the grounds that such decisions found that the Guidelines considered "evidence of a desire for rehabilitation," rather than "concrete evidence of a likelihood of successful treatment of the drug addiction ...." ${ }^{108}$ Thus, the court concluded that departure based upon evidence of a "substantial likelihood of successful drug treatment" was legitimate. ${ }^{107}$

This distinction-an objective, scientific assessment of the likelihood of rehabilitation versus evidence of a mere desire for rehabilitation-is troublesome. There seems to be little practical difference between a desire for rehabilitation and the likelihood of successful rehabilitation. In Harrington $I$, the court primarily relied on the court-appointed psychiatrist's report and the defend-

\footnotetext{
${ }^{101}$ Id at 652; Harrington $I, 741 \mathrm{~F}$ Supp at 976.

102 Harrington $I, 741 \mathrm{~F}$ Supp at 974-76.

103 Id at 977.

106 Id at 976-77.

106 Id at 977.

${ }^{106}$ Davis, 763 F Supp at 652 (emphasis on "desire" added).

107 Id.
} 
ant's dedication to his treatment program. ${ }^{108}$ The psychiatrists' conclusions in turn appeared to be based on the defendant's characteristics (maturity, sincerity, etc.) and the attitude he displayed in their meeting. In Davis the evidence mustered to illustrate that the defendant had a likelihood of successful drug rehabilitation largely consisted of the defendant's desire to rehabilitate herself as manifested by her participation in drug treatment at a halfway house. ${ }^{109}$ If the defendant's desire to undergo drug rehabilitation is a part of the defendant's acceptance of responsibility for a crime, it is hard to see how the defendant's likelihood of rehabilitation (which is essentially a desire to rehabilitate herself coupled with a few affirmative acts) is not also an acceptance of responsibility.

Judge Oberdorfer's solution is also potentially expensive and time-consuming. Presumably, every defendant who seeks departure based on her likelihood of rehabilitation would request, and be entitled to, a full battery of exams and tests, in the hopes that they would demonstrate a likelihood of successful rehabilitation. The court in Harrington II developed this point: "Reliance on 'scientific' predictions . . . could potentially transform sentencing under the guidelines into a battle of the experts . . . ."110

If all defendants are not entitled to such an examination, other problems arise. The expense of waging a battle of the experts might subvert the Guidelines' purpose: another similarly-situated defendant might not have the financial resources or judicial attention to be given the psychiatric examination and to procure credible expert witnesses. ${ }^{111}$ In short, this approach might lead to the very sentencing disparities that Congress sought to avoid in authorizing the Guidelines. ${ }^{112}$

These criticisms, however, are specific to the district court's approach in Harrington $I$ and Davis. While they do express significant concerns about the ramifications of the solution proposed in

${ }^{108}$ Harrington $I, 741 \mathrm{~F}$ Supp at 977.

${ }^{109}$ See Davis, 763 F Supp at 653 . The court also relied on the fact that the defendant had a strong family and a good counselor to support her efforts at rehabilitation. However, the Guidelines make clear that "family ties and responsibilities and community ties" are ordinarily not relevant in sentencing. See Guidelines Manual § 5H1.6 (cited in note 5).

210 Harrington $I I, 947$ F2d at 960. For a caustic critique of such reasoning, see Schulhofer, Assessing the Federal Sentencing Process (cited in note 80) ("One would have thought that if psychiatric issues are relevant to just sentencing, and if indigents lack access to necessary expertise, then an appointed expert should be provided. Indeed, the Supreme Court has already made clear that the Constitution requires no less.") (citing Ake $v$ Oklahoma, 470 US 68 (1985)).

11 See Harrington $I I, 947$ F2d at 960 .

112 Id. 
Harrington I and Davis, they do not constitute an argument that the Commission adequately considered post offense rehabilitation in the Guidelines.

\section{Proposed Solution}

This section proposes a resolution of the tension between the statutory arguments that led to the conclusion that post-offense rehabilitation has not been considered in the Guidelines, and the concern that departures for such rehabilitation will expend valuable judicial and correctional resources and lead to arbitrary disparities. A test that focuses on concrete steps the defendant has taken toward drug rehabilitation reconciles this tension.

Determining whether a departure from the Guidelines based on the defendant's drug rehabilitation is legitimate requires an understanding of what types of departures are available under the Guidelines. A close examination of the Guidelines reveals that there are several ways in which a court may depart from the sentencing range. ${ }^{113}$ In the context of the defendant's efforts at drug rehabilitation, two types of departure recognized in $\S 5 \mathrm{~K} 2.0$ are relevant: quantitative and qualitative departures. ${ }^{114} \mathrm{~A}$ sentencing court may make a quantitative departure when the Commission has considered a circumstance, but the circumstance exists in the case at hand to a degree not considered by the Commission. A qualitative departure is warranted when a defendant's circumstance is of a kind not considered by the Commission. This Section focuses on these two potential avenues of departure, and concludes that a departure based on the defendant's drug rehabilitation can take the form of a qualitative departure. Such a departure should

11s There are other types of departures that are not relevant here. See generally Alschuler, 117 FRD at 459 (cited in note 22). See Guidelines Manual § 5K1.1 (cited in note 5) (court may depart from the guideline range upon the government's motion when the defendant has provided "substantial assistance" to the authorities in the investigation or prosecution of another person); id at $\S 4 \mathrm{Al} .3$ (court may depart if the defendant's "criminal history category does not adequately reflect the seriousness of the defendant's past criminal conduct or the likelihood that the defendant will commit other crimes . . . "); id at $\$ \S$ 5K2.1-5K2.15 (the Commission explicitly stated that it did not "take into account fully" certain circumstances, thus inviting departure when they are present). Some offenses also contain provisions for departure unique to them. See, for example, id at § 2 G1.1 (recommending downward departure when offense did not involve physical force or coercion).

"14 The distinction is clear in id at $\$ 5 K 2.0$ (departure available when there exists "a circumstance of a kind, or to a degree, not adequately taken into consideration by the Sentencing Commission") (emphasis added). The terms "qualitative" and "quantitative" are borrowed from Sklar, 920 F2d at 115. 
be based on specific evidence of a defendant's affirmative efforts at drug rehabilitation.

\section{A. Quantitative Departure}

Even if the sentencing court concludes that the Commission did consider the prospect of the defendant's post-offense drug rehabilitation, a quantitative departure is still possible if the court feels that the defendant's conduct is sufficiently atypical to suggest that the Commission did not consider the conduct in such unusual form. In the context of drug rehabilitation, a quantitative departure requires a finding that the defendant has rehabilitated herself, made rehabilitative efforts, or has a potential for rehabilitation to a degree not recognized in the Commission's consideration of drug rehabilitation. Sklar, Harrington II, and Williams each allowed for the possibility of such a departure. ${ }^{115}$

However, this approach seems strained and may prove unworkable in practice. First, it is somewhat meaningless to speak of an "unusual degree" of drug rehabilitation. A genuine and complete rehabilitation prior to sentencing is certainly always an unusual situation. Allowing a departure when the defendant's rehabilitative efforts are truly unusual or extraordinary raises serious questions about what would make a rehabilitative effort unusual: its length? its intensity? its apparent success? the relative difficulty of achieving that success?

Any inquiry into whether a particular defendant's prospect of rehabilitation is sufficiently extraordinary to qualify for departure runs into the same concern expressed in Harrington II; sentencing under the Guidelines could turn into a battle of the experts. ${ }^{116}$ Nor is this concern limited to an inquiry into a defendant's likelihood of rehabilitation. The very standard that the court in Harrington II proposed-whether the rehabilitation itself is extraordinary-seems to inevitably lead to the "battle of experts" the majority feared. ${ }^{117}$ Asking which defendants have made extraordinary rehabilitations may only shift the battleground from the likelihood of the defendant's rehabilitation to the extraordinary nature of the rehabilitation. In short, allowing a quantitative departure based on the defendant's drug rehabilitation is not a workable solution.

\footnotetext{
215 Sklar, 920 F2d at 116; Harrington II, 947 F2d at 962; Williams, 948 F2d at 710.

${ }^{116}$ See text accompanying notes 110-12.

${ }^{117}$ See Harrington II, 947 F2d at 971 (Silberman dissenting).
} 


\section{B. Qualitative Departure}

Qualitative departures, those warranted by the fact that the Commission has not considered the kind of circumstance in question, have rightly received the most attention in the case law. As discussed earlier, ${ }^{118}$ no provision in the Guidelines constitutes a consideration of the defendant's drug rehabilitative efforts. Therefore, a qualitative departure based on the defendant's drug rehabilitation is legitimate. Such departures should conform to three conditions.

First, the grounds upon which a court may rely in making such a departure must be sufficiently circumscribed so as not to permit the court to tacitly reduce the sentences of all drug-addicted defendants. Addicted offenders who are out on bail may be entered into rehabilitative programs prior to their sentencing, ${ }^{119}$ and addicted defendants in custody can gain access to rehabilitative programs when possible. ${ }^{120}$ Allowing a downward departure every time an offender enters one of these programs could become a de facto reduction for drug-dependent defendants-a practical, if not outright, violation of $\S 5 \mathrm{H} 1.4$ 's proscription that drug dependency not be a reason for a downward departure. Second, if such departures were routinely granted, the frequency of departure would threaten to undermine the Guidelines' goal of uniformity. The grounds upon which a court relies in making a qualitative departure must be atypical. ${ }^{121}$ Finally, concerns about the expense of expert testimony and its potential to create the arbitrary disparities the Guidelines were designed to eliminate weigh heavily against any solution that requires such testimony. Limiting downward departure to those cases in which the defendant has exhibited genuine affirmative efforts at rehabilitation satisfies these concerns.

118 See Section II.

119 See Arthur W. Campbell, Law of Sentencing 332-33 (Lawyers Co-op, 1978)

${ }^{120}$ See Norval Morris and Michael Tonry, Between Prison and Probation 197 (Oxford, 1990).

121 Courts have sometimes referred to the Guidelines" "heartland" concept as a shorthand for the need to find atypicality. See, for example, Sklar, 920 F2d at 114-17. The Commission stated that it intended "the sentencing courts to treat each guideline as carving out a 'heartland, a set of typical cases embodying the conduct that each guideline describes. When a court finds an atypical case, one to which a guideline linguistically applies but where conduct differs significantly from the norm, the court may consider whether a departure is warranted." Guidelines Manual, ch 1 at 6 (cited in note 5). Other bases of the need for atypicality can be found in $\S 5 \mathrm{~K} 2.0$ 's provision that the circumstances relied upon "should result" in a lower sentence, and the provision in 18 USC $\$ 3742(\mathrm{k})(3)$ that a departure can be reviewed for its reasonableness. 
Requiring the defendant to have undertaken genuine affirmative efforts at drug rehabilitation mitigates the first two concerns by limiting the number of defendants who will be eligible for the departure. ${ }^{122}$ Not every drug addicted defendant will have made genuine affirmative efforts at rehabilitation; this standard allows the court to look for meaningful atypicality in the defendant's post-offense efforts. Requiring meaningful atypicality alleviates any concern over eviscerating the Guidelines' goal of increased uniformity. The third concern is satisfied as well. Unlike determining the defendant's prospects for rehabilitation, or the atypicality of such rehabilitation, affirmative efforts at rehabilitation would be fairly easy to identify and assess. Because such assessments are a matter within the ken of the trial court, extensive expert testimony would not be needed.

A potential shortcoming of this solution lies in its indeterminacy (just what are "genuine affirmative efforts"?), and the possibility that such indeterminacy will create the arbitrary sentencing disparities of the sort foreseen by the court in Harrington II. Resources dedicated to drug rehabilitation are limited; only a fraction of the defendants incarcerated prior to their trial who seek access to rehabilitation programs can be accommodated. Even for a nonincarcerated defendant, participation in a drug treatment program may be more a function of her lawyer's savvy or her financial means than an accurate gauge of her sincerity and progress toward rehabilitation.

This shortcoming is not fatal, however. First, there are several reasons to believe that district court judges can accurately assess whether a defendant has made genuine affirmative efforts at rehabilitation to merit a departure. Often, the sentencing judge will have an opportunity to assess the defendant's character firsthand. The judge is also privy to the probation officer's presentence report, which records the officer's firsthand observations and compiles information from the drug counselors with whom the defendant has worked. The impressive factual record compiled by Judge Oberdorfer in Harrington $I^{123}$ belies concerns over the district court's capacity to make such a determination.

122 In addition, this proposal shares an advantage with Harrington $I$ and Davis. By requiring more than the defendant's desire to reform herself, this proposal distances the grounds relied upon from the ostensibly attitudinal focus of $\S 3 E 1.1$. It also avoids focusing on the defendant's family and community ties, a consideration the Guidelines foreclose. See Guidelines Manual § 5H1.6 (cited in note 5).

${ }^{123}$ See text accompanying note 104. 
Also, departure should not be precluded merely because sentencing judges may have difficulty in assessing mitigating or aggravating factors. Such an argument would prove too much. Sentencing judges may not be able to perfectly sort those defendants who have made genuine affirmative rehabilitative efforts from those who merely participate in a rehabilitation program for appearance's sake at the sentencing hearing. However, these judges also cannot perfectly assess the defendant's acceptance of responsibility, ${ }^{124}$ or precisely determine whether the defendant's criminal history accurately reflects the likelihood she will commit further crimes, ${ }^{123}$ yet the Guidelines require such determinations. Any sentencing system that seeks to vary punishment based on a defendant's individual characteristics requires the judge to make speculative assessments that no human can possibly make with unfailing accuracy. If judges' lack of omniscience were a reason to forego making any individual determinations, the practical alternative would be to require the same sentence for all offenders who have committed the same crime.

Moreover, the Guidelines implicitly vest their confidence in courts to make a quite similar determination. When sentencing a defendant convicted of a drug possession or trafficking offense, $\S$ $5 F 1.6$ provides that the court may deny the defendant certain federal benefits. ${ }^{126}$ However, the application notes to $\S 5 \mathrm{~F} 1.6$ contain an exception:

[T] he period of benefit ineligibility shall be suspended "if the individual (A) completes a supervised drug rehabilitation program ... . (B) has otherwise been rehabilitated; or (C) has made a good faith effort to gain admission to a supervised drug rehabilitation program, but is unable to do so because of inaccessibility or unavailability of such a program, or the inability of the individual to pay for such a program. ${ }^{127}$

Importing the genuine affirmative effort standard into the decision to depart downward provides a means of distinguishing among defendants without creating disparities based on wealth or the fortuity of gaining access to a prison rehabilitation program. Again, this is not to imply that determining whether the defendant has made a "good faith effort" or "genuine affirmative efforts" is a

124 Guidelines Manual § 3E1.1 (cited in note 5).

${ }^{125}$ Id at $\S 4 \mathrm{A1} .3$.

${ }^{126}$ Id at $\S 5 \mathrm{~F} 1.6$.

${ }^{127}$ Id at $\S 5 \mathrm{~F} 1.6$ (commentary) (quoting 21 USC $\S 853(\mathrm{a})(\mathrm{c})$ ). 
foolproof process. It does demonstrate, however, that Congress believes that these are determinations which judges have made and can continue to make.

Even if sentencing courts fail to exercise circumspection when granting departures on the basis of drug rehabilitation, the departure is subject to appellate review of the "reasonableness" of the departure. ${ }^{128}$ Appellate court review of the reasonableness of the departure will significantly alleviate the fear that such departures will be tantamount to a tacit sentence reduction for all addicted defendants or expand to the point that they jeopardize the Guidelines' goal of uniformity.

\section{CONCLUSION}

The Guidelines are a revolutionary system of sentencing. Obeying them, in letter and in spirit, will certainly require courts, as Judge Wilkins put it, to "put some of the practices of the past aside." 129 Nonetheless, the simple fact that the present system vests less discretion in the sentencing judge is not a talisman for the resolution of all disputes over the scope of the departure privilege. A close reading of the Guidelines reveals that they do not preclude departure based on the defendant's genuine affirmative efforts at rehabilitation. Nor is such a departure privilege inconsonant with the philosophy or practical workings of a guideline system. A principled and restrained application of such a departure privilege can only contribute to a coherent and just sentencing system. $\dagger$

${ }^{128} 18$ USC $\$ \S 3742(e)(3), 3742(f)(2)$. Lower courts have taken varied approaches when applying the reasonableness test. Compare United States v Lira-Barraza, 897 F2d 981, 983 (9th Cir 1990) (using the reasonableness standard to test the "extent or degree of departure"); with United States v Mejia-Orosco, 867 F2d 216, 219 (5th Cir 1989) (using the reasonableness standard to test the reasons offered for departure). Dictum in the Supreme Court's recent pronouncement on the appellate review of departures seems to favor the Lira-Barraza approach. See Williams v United States, 112 S Ct 1112, 1121 (1992). However, even if the explicit reasonableness test of 18 USC $\$ 3742(\mathrm{e})(3)$ applies only to the extent of departure, the "should result" language of $\S 5 \mathrm{~K} 2.0$ and the "heartland" concept, see note 121, justify appellate review of the reasonableness of a district court's decision to depart.

129 Van Dyke, 895 F2d at 987.

† Editors Note: On May 11, 1992, after this issue went to press, the Sentencing Commission submitted an amendment to $\S 3 \mathrm{E} 1.1$ of the guidelines, the acceptance of responsibility adjustment, designed to foreclose departure by allowing consideration of post-offense rehabilitative efforts in assessing the defendant's acceptance of responsibility. See 57 Fed Reg 20148, 20156 (1992). If Congress does not act on this amendment prior to November 1, 1992, the amendment will take effect at that time. See id at 20148; 28 USC § 994(p) (1988). 